<㱏例報告 $>$

塩酸フルナリジンが有効であったアルコール性肝硬変症に 合併した spur cell anemia の 1 例

$\begin{array}{lrrrrrrr}\text { 吉田 } & \text { 守 } & \text { 中島 } & \text { 洋 } & \text { 和田 } & \text { 修 } & \text { 江渡 } & \text { 博之 } \\ \text { 富井 } & \text { 重明 } & \text { 尾崎 } & \text { 椇人 } & \text { 長谷 } & \text { 章 } & \text { 高橋 } & \text { 信一 } \\ \text { 斎藤 } & \text { 昌三 } & \text { 青柳 } & \text { 利雄* } & & & & \end{array}$

要 旨：症例は53歳，女性. 肝機能障害，黄疸，貧血の精查の目的で当科に入院。肝は腹腔鏡 検查, 肝生検でアルコール性肝硬変症に相当する所見を呈し，末梢血塗抹標本で有棘赤血球 （spur cell）を多数認め，諸検査成績より，他の溶血性負血を否定できたため，本例はアルコー ル性肝硬変症に合併した spur cell anemia と診断した。肝庇護療法で症状の改善をみないため, 持続性 $\mathrm{Ca}$ 拮抗剤である塩酸フルナリシン $20 \mathrm{mg} /$ 日の投与を開始したところ，負血と黄疸の改 善を認め, 末梢血の spur cell あ消失した. Spur cell anemia は肝硬変症, とくにアルコール 性肝硬変症に急性に強い容血発作が起こってくるもので, 予後は不良とされ，その治療法はま た確立されていない，本例では塩酸フルナリシン投与後に，蔶血，黄㾝の改善を認め，塩酸フ ルナリジンが有効であったアルコール性肝硬変症に合併した spur cell anemia の 1 例と考えら れた。

臬引用語： spur cell anemiaアルコール性肝硬変症＼cjkstart塩酸フルナリジン

\section{緒言}

1964年 Smith ら"は，アルコール性肝硬変症に合併 した高度の容血性費血の 1 例を報告し，その末梢血に 特異な突起を有する赤血球を認めたことから,“spur cell anemia”と名づけた。 以来, spur cell anemia の 報告が散見されるが，その予後俚不良とされ，その有 効な治療法もいまだ確立されていない。

1983年, Fossaluzza ら²は spur cell anemia の治療 に塩酸フルナリジンが有効であった 2 例を報告した.

我々もフルコール性肝硬变症に合併した spur cell anemia に同剤を投与し，臨床的に有用であった症例 を経験したので，若千の文献的考察を加光報告する．

症例

53歳の女性.

主訴：肝機能障害，負血.

家族歴：母忽気管支喘息。

既往歴：特記事項なし，輸血歷なし。

飲酒歴：28葴よりビール2 3 本/日.その後, 次第

•杏林大学第 3 内科

〈受付日1992年 2 月19日 $>$
に飲酒量が増加し, 50 歳頃よりウイスキーボトル 1 本/ 3 日。

現病歴：1985年11月, 近医で初めて肝機能障害を指 摘されたが，その後は通院せず拎酒を継続していた。 1986年 1 月頃より, 眼球黄染, 腹部膨満感, 鼻出血が 出現した。食思不振，腹部膨満が著明となり，同年 5 月フルコール性肝硬変症, 溶血性蔶血の診断で, 近医 に入院した，入院後 $\mathrm{Hb} 6.2 \mathrm{mg} / \mathrm{d} l$ まで低下したため に, 輸血を棇量 $3,800 \mathrm{~m} l$ 施行したが改善せず, 精查加 療を目的に同年 9 月当科に入院した.

入院時現症：身長 $153 \mathrm{~cm}$ ，体重 $48 \mathrm{~kg}$. 意識清明．血 压 $120 / 70 \mathrm{mmHg}$ ，脈拍 $72 /$ 分 (整). 瞼結膜に貧血，球 結膜に黄疾を認め，全身の皮庙に暗赤色の色素沈着を 認めた，表在リンバ節は触知せず。心肺に異常所見を 認めず．腹部では肝脾触知せず，腹水も認めず，下肢 に浮腫なし. 神経学的に異常所見なし。

検査所見 (Table)：末梢血検查にて Hb $10.8 \mathrm{~g} / \mathrm{d} l$, MCV 102.4と, 大球性負血を呈し，凝固能。 PT $29.2 \%$ ，HPT $47.5 \%$ 之著明な低下を認めた。

生化学検查では間接型優位のビリルビン增加を認 め，LDH の増加 (フインザイムでは LDH1偍位) と総 
Table Laboratory findings on admission

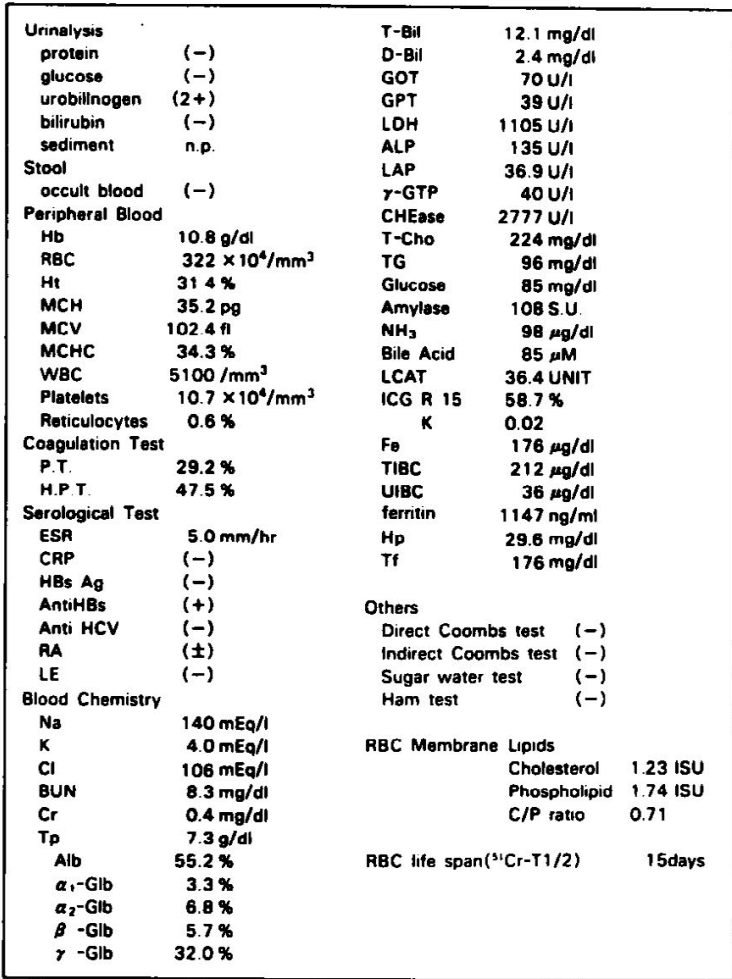

胆汁酸の増加, 総コレステロール値, 中性脂肪は正常 筑囲であるがLCATは低値，ICG 15分停湍率は $58.7 \%$ と高値であった。

赤血球膜の脂質分画でコレステロールが1.23ISU 之增加（正常値0.6 0.8）乙，リン脂質は正常範囲で, コレステロール/リン脂質比は0.71であり,赤血球寿命 は15日と半减していた。

画像診断：腹部 US 像, 腹部 CT 像, 肝シンチクラム で，肝硬変症に相当する所見であった，

腹腔鏡像所見 (Fig. 1)：肝右葉はやや萎維し色調は 黄色調で，辺縁は鈍化し表面は細顆粒状を呈し，多数 のリンパ小水疮を認めた. ICG $3 \mathrm{mg} / \mathrm{kg}$ 静注による色 素腹腔鏡検㚗では，15分後の着色をほとんど認めな かった.

肝生検組織所見 鍍銀染色 (Fig. 2)：比較的幅の狭 い間質からなる微細結節性肝硬変であった。なお $\mathrm{HE}$ 染色像では，肝細胞内に一モジデリン色素の沈着を多 数認め，鉄染色像でも著明な鉄の沈着を認めた。

末梢血洨潇 May-Giemza 染色(Fig. 3)：变形した 赤血球を約 $40 \%$ 認め，走査電湿像 (Fig. 4)では突起の

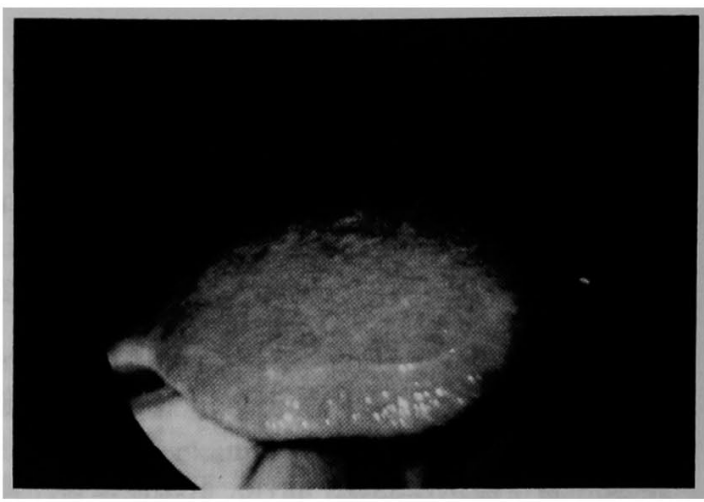

Fig. 1 Laparoscopic view of the right lobe of the liver.

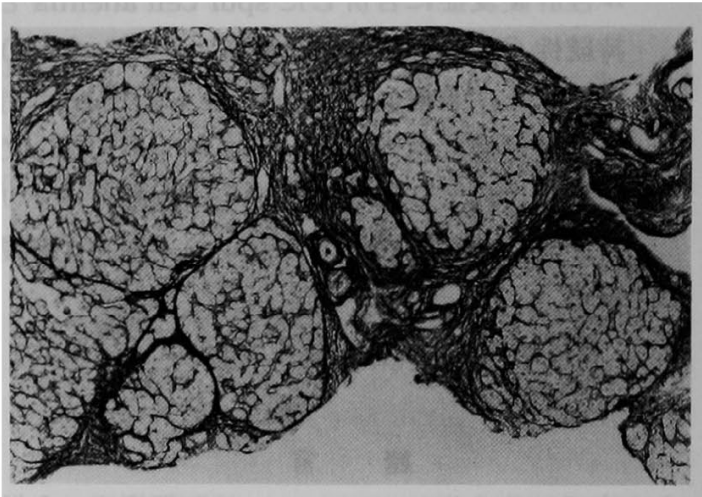

Fig. 2 Biopsy specimen shows cirrhosis with well developed pseudolobules. (Silver stain)

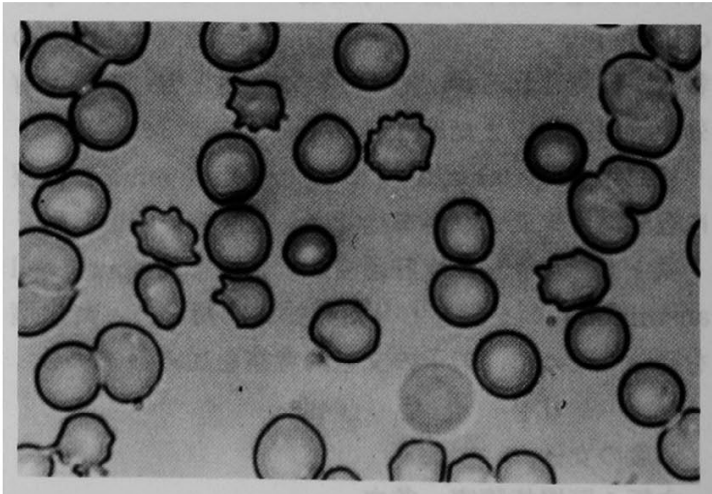

Fig. 3 Peripheral Blood smear. (May-Giemsa stain)

先端が丸みを括びた金平糖様の有棘赤血球を認めた。 以上，本例はアルコール性肝硬変症に溶血性蚠血を合 併し，末梢血中に有棘赤血球を認め，諸検査より他の 


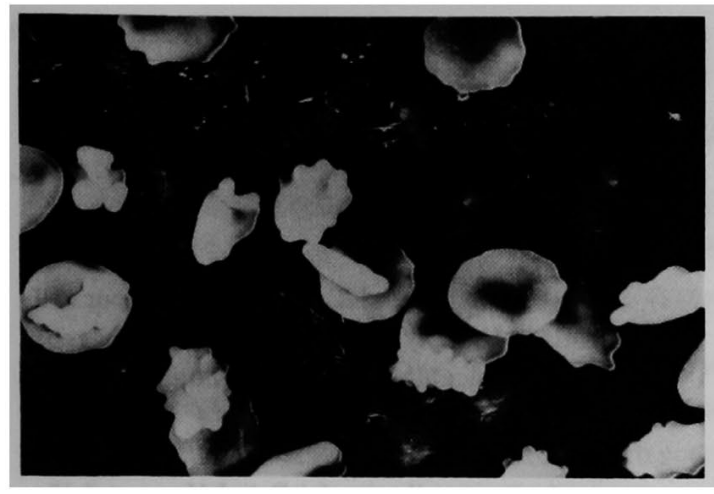

Fig. 4 Peripheral Blood smear showing spurshaped erythrocytes. (Scanning electron microscopy)

溶血性貫血を否定できたため spur cell anemia と診断 した.

\section{経過 (Fig. 5)}

䏕庇護療法にて臨床症状の改善をみないため, 塩酸 フルナリシンの投与を開始したところ，徐々に負血，

黄㾝の改善を認めた。

飲酒は1986年 5 月，近医に入院するまで続けていた か，当院退院後1987年12月頃まで禁酒していた，1988 年 1 月より約 2 カ月間, 领酒を続け，肝機能の増悪之 負血, 黄庭の増強を認め， 3 月再入院となったが, spur cell anemia は認められず，赤血球膜のコレステロー ル/リン脂質比も0.51と低下していた。

塩酸フルナリシンは約 2 年 6 カ月間継続投与した 後, 中止したが経過良好である。

\section{考察}

Spur cell anemia はフルコール性肝硬变患者に特有 な变形赤血球をともなった溶血性負血を認める病態 で, 1964年 Smith ら”により初椵告された。 その臨 床的特峘は，1）重症の訮硬変，特にアルコール性肝硬 変症，2）急性で強い溶血発作，3）間接型ビリルビン 優位の黄宣，4）末梢血液中に spur cell の認められる 事, 及び，5）予後不良である事，であり，我々の症例 む1－4)の特徵に一致する.

Spur cell anemia について, Cooper $ら^{3,4}$ は, 詳細 に症例を検討しており，血清及び赤血球膜の脂質構成 の異常と脾脭の関与する事を指摘し，その出現機序に ついて 2 段階に分けて説明している.

まず,血清コレステロールが赤血球膜へとりこまれ, 膜の脂質不均衡を生じ， scalloped cell（ホタテ貝）様 に变形し，次に脾喴にとりこまれ， spiculaを有する spur cell へと移行し，容血しやすくなると考えた. 従って，赤血球膜のコレステロール/リン脂質 $(\mathrm{C} / \mathrm{P})$ 比は, $1.32 \pm 1.8$ (コントロール0.9 0.05 ) と上昇を 認めた。 その他の報告ですその比は Silber ら50.60,

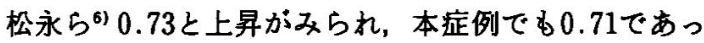

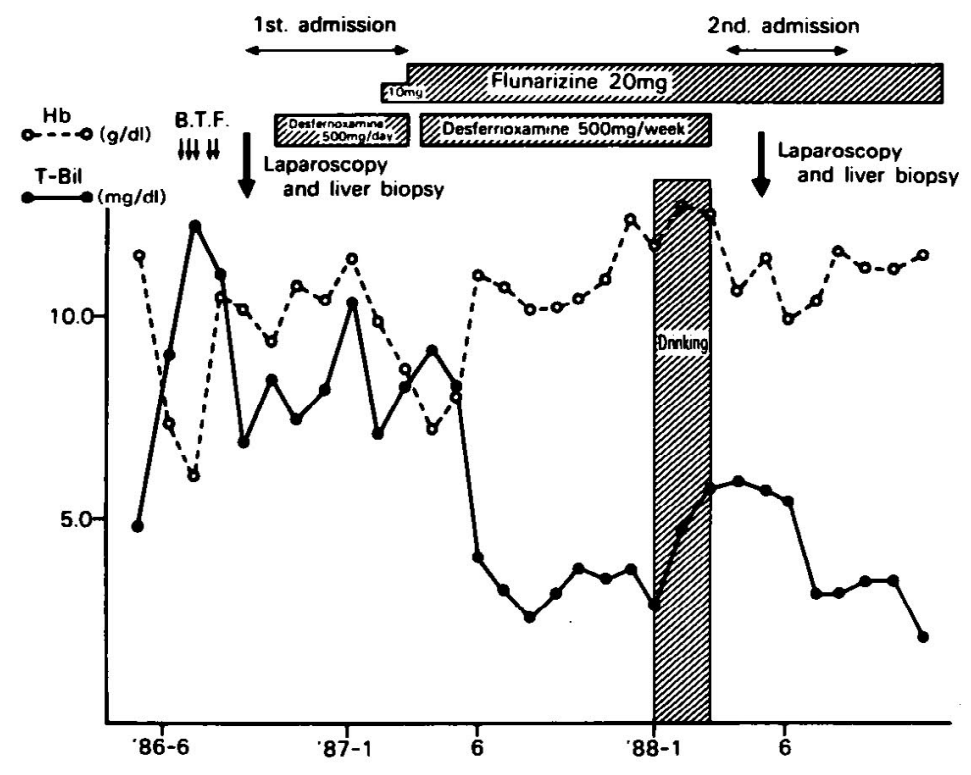

Fig. 5 Clinical course 
$36: 620$

周

に事より spur cell の成立には赤血球膜の C/P 比が重 要な役割を果たしていると考えられる。

また, spur cell は最初, 先天性 $\beta$ リポ蛋白欠損症と アルコール性肝硬变症においてみられるとされていた が, その後ウィルソン病”や胃癌の術後で認められた といら報告8すみられれ， spur cellの出現には必ずし すフルコールや肝硬変症は闺係がないと考えられ，そ の発生機序はいまだ完全に解明されたとはいいがた い.

一方, spur cell anemia を合併した肝硬変症の予後 は数カ月で死の転㷌をとる，極めて重篤な状態とされ， その治療法はまた確立されていない，摘脾や，リン脂 質の静注法, コレスチラミン,ネオマイシン併用療法, 及び血䟿交換療法"日試みられているがあまり有効で はない.

Fossaluzza ら² は spur cell anemia に塩酸フルナリ シンを投与し有効であった 2 症例を報告した。

また，本邦でる1987年水毛生ら ${ }^{10)}$ が同剂を投与し有 奻であった 1 例を報告している。

塩酸フルナリシンは作用持続性の Ca 拮抗剤で脳血 管に選択的に作用し脳血流量を増加させるとされてい るが，同時に赤血球変形能の减弱防止効果ああるとさ れている。

渡辺ら ${ }^{11)}$ は赤血球変形能に及ぼす $\mathrm{Ca}$ 拮抗剤の影響 について検討し、Ca 拮抗剤は赤血球变形能阻害作用を もち，その作用は Caイオンの赤血球内流入阻害効果 であるとしいる。

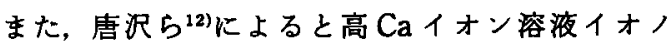
フォア A23187で作成された変形赤血球に対し，種々 のCa 拮抗剂を投与したところ，塩酸フルナリシンの みがその変形を防止したという．その機序として，イ オノフォフによる変形は, 赤血球外液 $\mathrm{Ca}$ イオンの赤 血球内流入に基つく赤血球収縮蛋白質の活性化による あのと考えられ，そのCaイオンの作用を塩酸フルナ リシンが阻害するとしている.

本症例は塩酸フルナリシン投与後, 貣血, 黄疸は改 善し，末梢血中の spur cell b消失した事や，その他の 生化学デー夕す改善傾向を示した事から, 本治療はそ の作用機序の詳細はまた不明であるが, spur cell anemiaに有用であると考えられた。

\section{結語}

フルコール性肝硬変症に合併した spur cell anemia に抗 $\mathrm{Ca}$ 拮抗刘塩酸フルナリシンが有用であった 1 例 を報告した。臨床症状や検査所見の改善をみた点など
から，本治療は今後試みられるべき治療法と考えられ た.

本症例の要旨は第23回肝缄学会東部会に於いて報告し た.

\section{文献}

1) Smith JA, Lonergan ET, Sterling K : Spur cell anemia: Hemolytic anemia with red cells resembling acanthocytes in alcoholic cirrhosis. N Engl J Med 271 : 396--398, 1964

2) Fossaluzza V, Rossi P: Flunarizine treatment for spur cell anemia. Brit J Haematol 55 : 715-717, 1983

3) Cooper RA, Kimball DB, Duocher JR: Role of the spleen in membrane conditioning and hemolysis of spur cells in liver disease. N Engl J Med 290 : 1279-1284, 1974

4) Cooper RA, Arner EC, Wiley JS, et al : Modification of red cell membrane structure by cholesterol-rich lipid dispersions: A model for the primary spurcell defect. J Clin Invest 55: 115-126, 1975

5) Silber R, Amorsi E, Kayden HJ, et al : Spurshaped erythrocytes in Laennec's cirrhosis. $\mathrm{N}$ Engl J Med 275 : 639-643, 1966

6）松永㙂雄，中川昌壮，高野俊男，他：Spur cell anemia を来たし肝不全で死亡したアルコール多 领者の 1 剖検例。肝葴 $18: 49-57,1977$

7) Cooper RA: Hemolytic syndromes and red cell membrane abnormalities in liver disease sem. Hemat $17: 103-112,1980$

8）山田英雄, 上田能三，堀田知光，他：胃癌末期にみ られた Spur cell anemia と思われる症例，厚生省 特定疾患溶血性貟血調查研究班，昭和 49 年度報告 書, p91-95, 1974

9）武元良整，山本栄一，藤井千穗，他：Spur Cell Anemia に対する血䠌交換の释験. 臨床血液 26 ： 259-262, 1985

10）水毛生直則, 織田邦夫, 能登 稔, 他 : Spur cell anemia と思われる溶血性蔶血を合併した肝硬変 の 1 例 flunarizine Kよる 1 治検例. 日内会誌 $76: 1463,1987$

11）渡辺泰雄，今西信幸，志村容生，他：赤血球变形能 に及ぼすCa 拮抗薬の影雯。東京医科大学誌 44 : $841-847,1986$

12）唐次 啓, 久保和博, 山田耕二,他：イオノフォフ A23187によるヒト赤血球の形態变化と Flunarizine によるその変形阻止作用について，基礎と臨 床 $16: 142-147,1982$ 


\title{
A case of spur cell anemia with alcoholic liver cirrhosis successfully treated with flunarizine hydrochloride
}

\author{
Mamoru Yoshida, Hiroshi Nakajima, Osamu Wada, Kiroyuki Eto, Jyumei Tomi, \\ Makoto Ozaki, Akira Hase, Shinichi Takahashi, \\ Shozo SaITo and Toshio AOYAGI*
}

The patient was a 53-year-old woman who admitted to our department for a close examination for jaundice, and anemia. Through peritoneoscopic examination and liver biopsy, the liver surface pattern and histologic findings of liver specimen are compatible with alcoholic liver cirrhosis. An examination of the peripheral blood smear showed spur cell anemia. As a result of alcoholic liver cirrhosis complicated with spur cell anemia was diagnosed. The administration of $20 \mathrm{mg} /$ day of flunarizine hydrochloride (anti calcium antagonist) resulted in an improvement of anemia and jaundice, with the disappearance of spur cells. Spur cell anemia often develops in patients with alcoholic liver cirrhosis, and associated with acute, accentuated hemolytic attacks. Its prognosis is believed to be poor and its therapeutic modality has not yet been established. The present case showed an improvement in anemia and jaundice following the administration of flunarizine hydrochloride. Thus it was concluded that this agent was effective in the treatment of spur cell anemia complicated with alcoholic liver cirrhosis in this case.

* The Third Department of Internal Medicine, Kyorin University School of Medicine (Tokyo) 